\title{
What now of the Vashti character in the Hebrew Bible? Ruminating on the future of the Circle of Concerned African Women Theologians among emerging scholars in Democratic Republic of the Congo
}

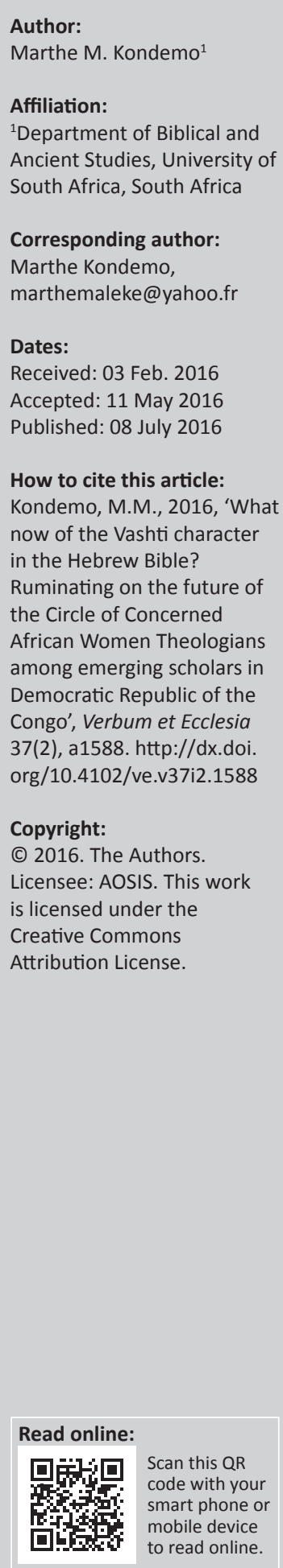

Concerned about the relative absence of activities (including the writings) by members of the Circle of Concerned African Women Theologians within the Democratic Republic of the Congo Circle, Francophone context in general and her Mongolese context in particular, the author uses the marginalised character of Vashti in the Hebrew Bible to see which light the character might shed within the preceding contexts. Can Vashti's identity in terms of boldness, courage and independence serve as a model for Congolese women in their efforts to make a positive impact on their contexts which remain glaringly patriarchal even today after many years of political independence? In this article, it is argued that the character of Vashti, especially her sense of independence and courage, can serve as a motivation for Congolese female theologians in their search for new identities.

Intradisciplinary and/or interdisciplinary implications: In this article, the disciplines of African studies, political science, gender studies and biblical studies are made to interact with each other in the author's quest to see how a biblical character such as Vashti can contribute positively to the theory and praxis of theology among emerging Francophone female scholars.

\section{Introduction}

Women's concerns have been the subject of various debates in the last three decades. Women's issues have become a special area of interest to policymakers, researchers, educators and human rights activists because of the assumption that women are marginalised and deprived in many ways. On the whole, many women are still not as educated as men. They do not enjoy power, opportunity, privilege and recognition in the same way as men. They are inhibited because of restrictions imposed by tradition and culture (Edewor 2001:35). However, the role of women is changing dramatically in modern times and today we are witnessing the rebirth of the African woman as free, intelligent, dynamic, determined and responsible. She acts as a partner, colleague, supervisor, manager and friend with whom it is possible to have interesting and constructive conversations on various topics.

The idea of women as professionals or participants in social and economic activities outside the home is increasingly becoming acceptable all over the world. Thus, the image of the girl-child who is unable to assume any serious responsibility, who is fearful before a man, and who needs to be protected and supported is fading gradually. The faithful woman who always cares for her family is no longer a fragile person but a very active, competent and responsible woman who is also a good home manager. There is no doubt that much progress needs to be made with respect to the affirmation of women's roles and responsibilities, access to resources, and knowledge of and participation in strategies to improve the situation brought about by male domination, globalisation and marginalisation.

Therefore, this article serves as a call for Congolese female theologians to revisit their role and place within the church ${ }^{1}$ and the society. It should serve as an encouragement to revisit or establish a Circle chapter in the Democratic Republic of the Congo (DRC) that in my view should be an open space where women can come together to discuss their approaches and the content of their theology following the objectives of the Continental Circle that focus on women's liberation and the creation of women's theology (Fiedler \& Hofmeyr 2011:56). The character of Vashti in the book 1.This article focuses on the Church of Christ in Congo (ECC). ECC is an association of all Protestant Churches in DRC under one leader.
Due to the scarcity of written records that are relevant to the research topic, this section relies mainly on the general context of the DRC as well as on the researcher's observations and experiences as an insider. 
of Esther will also be reread in a way to empower Congolese theologian women in their fight for an equal society.

\section{Women's role and place in the Democratic Republic of the Congo}

There is no doubt that women have been victims of gender ideology in the Mongo society. A woman is not considered an equal human being to a man and a married woman is considered one of a man's possessions. A man is superior, strong and can get away with anything but the woman is supposed to stay at home to bear children and be faithful and submissive to her husband. She is portrayed as a virtuous happy housewife who is submissive, faithful, and selfsacrificing (Hulstaert 1964:22). In such a situation, a woman's role determines her destiny. She is regarded as a weak creature who needs male protection at all times. A woman is also regarded as a seductress who like Eve in Genesis 3 is a source of temptation. The image once again limits her freedom, her initiative to develop her personality and confidence in her abilities. She is viewed as a man's property that is transferred from father to husband (Hulstaert 1964:21). A woman is portrayed as less important than a man and thus deserving fewer privileges. Such a portrayal thwarts her aspiration and also lowers her expectations and self-respect. Thus, a Mongo woman can be used or abused by her husband without any intervention from outside. Even when she is the victim of abuse by an outsider, society considers that the abuse brings dishonour to her father, husband or brother rather than to the victim. Furthermore, she is considered a sex object who was created for a man's pleasure. The above representations of women have remarkably influenced the roles of women and their identities in the Mongo society causing women to believe that they are worthless, incapable of making decisions on their own and needing protection and support from men.

In the DRC, although some efforts have been made to develop more gender-sensitive policies and programmes and to open up opportunities for women, women continue to be left behind in almost all aspects of life. It is difficult - not impossible as argued by Mbuy-Beya (1996:176) - to discuss women's issues in the church without first examining the oppression that women experience in the society. As argued by Mbuy-Beya, the church as well as all other organisations exists within the society. Therefore, talking about women should involve the society as whole. The perception of women in the church is not so different from that in the society. The church itself does not escape the temptation to discriminate against women. The inferior status of women is entrenched in history, culture and tradition; and throughout history, national and religious institutions have been evoked to justify the violation of women's rights to equality and of their fundamental human rights. Until now, women are subject to discrimination in every aspect of life - in terms of income, education, health and participation in society and they are particularly vulnerable to gender-based violence, human and sex trafficking, and sex discrimination
(Olatundun 2010:35). In spite of notable progress in different areas, gender inequality persists.

Religion also plays a huge role in the promotion of gender inequality in the DRC. Because the religious structures and hierarchies are male-dominated, their patriarchal character does not favour the course of women. As mentioned above, the status of women in the church reflects their status in the society. Discriminatory treatment of and teachings against women are not only perpetrated by the society but also by the church. For centuries, women member of several churches of Christ in Congo $^{2}$ (ECC) have been denied ordination while the study of theology has been dominated almost entirely by men (Kondemo 2015:91). In all its history, the Church of Christ in Congo (ECC), with more than 62 different member churches, has never had a woman in a leadership position, that is, as bishop, general secretary, president or deputy president in any of its member churches.

Although many missionary churches have allowed women to study theology, such women are only allowed to work as church ministers or in women and children's departments of the church. Given the fact that in the DRC, theological study is connected to churches and one therefore needs a recommendation from the church to be admitted to a theological school, many women are unable to access theological education even if they sense that they have a special call to work for God because the church refuses to recommend them. Instead of enrolling in a theological school because they have been called, many women do so because of their connection to church leaders. Today, it has become a practice for male theologians in leadership positions in the church to send their wives to theological schools. These men are often ready to support their wives to study theology at a higher level. However, it should be acknowledged that even though many churches impose restrictions on women's theological training, some men in key positions in the church and overseas' sponsors encourage women to undertake such training.

Only recently, some universities have started to employ women as junior lecturers, a move which opens a door of opportunity for them to enrol in postgraduate studies. Thus, it is clear that it would have been difficult for the few women in theology to study without the support of men or the maledominated international organisations which sponsor their churches. However, gender studies, as a course, is not promoted in many universities because it is viewed as a new concept that might upturn the normal setting of the society. There is a fear on promoting gender studies because of the misconceptions of what is understood by gender analysis. This challenge, according to Phiri (2008:13), can only be expelled through a balanced education of all the people of God. In her view, there is a need to educate the churches and theological institutions locally and globally that the community of women and men should work together to

2.For example, in my church, Association of Evangelical Churches along the Congo River (CADELU), only after 120 years of its existence were women allowed to study at theological institutions. In that context, marriage is one of the main conditions to be ordained. Until today, CBCA (a Baptiste church) does not ordain women. 
decide on the type of theology that should be taught in the theological institutions.

Although there is progress in gender issues, many female theologians continue to play inferior roles as compared to male theologians. As argued by White (2015:2) in an African context, female theologians remain the subject of various issues and controversies in the church. Is a woman equal to a man? Can she exercise the same spiritual gifts as men in the church? These questions remain a challenge and always lead to serious debates in the church where women are treated as inferior to men and do not have the same rights as men. Once their studies are completed, female theologians are assigned to work in the church as ministers or they are put in charge of women's projects.

In some churches, women's ordination or appointment as ministers is viewed as upsetting the natural order. In the context of the Democratic Republic of Congolese church, for example, women serve as Sunday school teachers, church secretaries, custodians, and deaconesses while many more manage and provide for social functions, sing in choirs, and, perhaps most significantly, raise money. As Mbuy-Beya (1996:187) has remarked on women's involvement in the church, 'they are seen in their activities in the liturgy, they devote their talents to the choir, direct and guide the young, proclaim the word of God and at the offertory and alongside the men, they offer to God the fruit of the earth, the work of their hands'. Even though women dominate the pews, they are absent from the power structures.

Although the church has allowed women to be educated and to work in the church, in many cases, their role remains inferior to men and most women are sent to work in rural and small parishes. Women have to work hard to make their way up and prove that they can perform as well as or even better than their male colleagues. The church continues to play an important role in defending the cause of women in different ways but the effort does not effectively transform the roles and identities of women. Despite the values they defend publicly, churches remain deeply conservative about the roles assigned to women in the public sphere. There is generally little representation of women in positions of leadership. As a traditional institution, the church has continued to perpetuate certain traditions for several generations including fundamentalist teachings and interpretations of the Bible which emphasise the authority of men over women and women's submission to men. Indeed, it is evident that DR Congolese women have benefited greatly from the church. However, Christianity continues to legitimise and reinforce the subjugation of women by men. Without any support system, DR Congolese women theologians remain without a voice and bear their struggle and suffering in silence. The book of Esther with its patriarchal setting is among those books that reinforce the subordination of women. In such a context, can the character of Vashti in the book of Esther if read from a gendersensitive point of view serve as a model that should motivate Congolese women theologians to stand and combat the inequality?

\section{Reading the Vashti character to empower the Democratic Republic of the Congo Congolese female theologians}

The book of Esther is a patriarchal text that reflects and reinforces patriarchy portraying the male fantasy of a female heroine but Esther can also be read as a story that liberates and empowers women. Zonana (1996) confirms:

\begin{abstract}
... Yet the book of Esther tells a story in which women's power is not so much repressed as asserted. The king who banishes one queen finds himself submitting to the will of another; liberal feminist readers in the nineteenth century might find in Esther an empowering story of women's emergence from oppression: a story of divine providence that could amply justify - and represent - the contemporary struggle for women's social advancement and emancipation. (p. 230)
\end{abstract}

Vashti's story found in the book of Esther is only one of the many stories in the Hebrew Bible which portray women negatively. Vashti's story (Es 1:10-21) is a very short part of the entire narrative. Immediately after she was introduced, she disappeared from the story. Vashti is introduced during the second drinking party. She is identified as a queen, the king's wife. On the seventh day (Es 1:10-12), when the king was merry with wine, the drunken king commanded his seven eunuchs to bring Queen Vashti 'into the presence of' the king. There is no clear or exact justification for summoning Vashti. Perhaps the king acted out of insecurity or the desire to show off his wife's beauty to the guests. Just as the king displayed his honour and wealth, he also wanted to display one of his possessions - his wife. Nadar (2002:121) notes that the king summons Vashti to appear in her capacity as a woman - a sexual object. Her appearance before the king and his male guests was desired to confirm her value as a beautiful possession and to earn the king respect before his guests.

In the book of Esther, Vashti is seen as a brave woman who risked her life based on her conviction and said ' $\mathrm{No}^{\prime}$ to the king's request. Rabbinic commentaries have justified Vashti's refusal on the assumption that the king wanted her to appear wearing only the royal crown (Day 2005:30). She was supposed to appear naked before the king and his guests. Some have suggested that Vashti was busy socialising with other women at her own banquet (Comstock 1993:53). In light of the above discussion, it seems that Vashti acted wisely. As Goitein (1959:61) argues, 'we all feel that Vashti is right in not prostituting herself before the drunks on the seventh day of the feast, when the wine has aroused them powerfully'. According to the narrative, Vashti is banished not because of her disobedience but because of the possible effects that her action would have on other less powerful women who would follow her lead to disobey their husbands. Vashti is regarded as a revolutionary because through her 
action, she was able to show the men that a woman also has a will. In Biblical Israel, women were almost exclusively confined to the home where they played the primary role of household managers and performed wifely and maternal duties (cf. Pr 31:10-31). That ancient situation is comparable today to that of women in the DRC's patriarchal society where women are not regarded as equal to men. Women were or are expected to be humble, patient, obedient and hardworking while men make decisions for women to implement. Even though no reason was given for her rebelliousness, I regard Vashti as a symbol of hope for women who need to affirm themselves. Most successful liberation movements are the result of much struggle and sacrifice (Kondemo 2015:130).

Lessons learned from Vashti could empower women to act in their situation and help men to create space for women to redefine themselves. Vashti is seen as a rebellious wife who refused to appear when her husband summoned her. Her story is seldom remembered in our congregations. Church members talk about Vashti only in passing as though she does not belong to the Esther narrative. Within the Congolese church, Vashti's character is depicted negatively and she is mentioned only in some sermons in contrast to Esther who is upheld as a model and is usually at the centre of such sermons. In Christian tradition for example, there is hardly any admiration for Vashti. The image one derives of Vashti depends on one's starting point. Interpretations that are rooted in patriarchal views are often quick to assign as much blame and negativity to Vashti as to the king even when they try to excuse Vashti's refusal. Although the negative portrayal of Vashti has greatly influenced the interpretation of Vashti's character among Christians, the story of Vashti can be reread in different ways. Vashti's refusal means more today than it must have meant in the past. Revisiting her character in our modern context leads to a new way of reading the Bible. As Tamez (1994:190) has observed, 'A reading of the Scripture that truly liberates responds to the situation that has motivated the reading'. Readers should read the story of Vashti with new eye in a way to find solution to their own situation within their context. It is only via such readings that we can begin to challenge the negative foundations and constructs of society in order to establish justice and change.

Vashti's simple action of refusal created fear and shock in the ruling hierarchy. Notably, 'The response to Vashti's refusal ... is presented as at once both dead serious and comically overblown' (Beal 1997:11). Perhaps it was the wine and drunkenness from the weeklong party that caused the men's emotions to be overblown, as 'Vashti has also exposed the vulnerabilities and fragility of dependencies of this patriarchal order' (Beal 1997:16). In a very simple way, Vashti took action by just saying no. Later in the book of Esther however, the king changed his style of decision-making. Vashti becomes a symbol of resistance, a symbol of what it means to speak up. Like Vashti, women who resist patriarchy are usually dismissed to keep them silent and submissive.
How then could Vashti serve as a model that should empower Congolese women theologians?

Although Christian doctrines have been used to subordinate women in many ways, in some denominations, they have been used also to legitimise women's voices and claim to spiritual (if not social) equality. Vashti was portrayed as a negative role model with whom a man would not want his wife to associate. By her refusal, Vashti portrayed herself as the agent of her own action. She confronted the abusive male power structure. Vashti's refusal represents a courageous act in the face of a male-dominated society. The brief act of Vashti's resistance set the stage for Esther and her future manipulation of the king showing that patriarchy is strengthened only when women encourage it.

Lerner (1986:217) notes that patriarchy cannot function without women's support. Women have helped men to perpetuate patriarchal norms in all generations. They make themselves available to serve and obey men. Therefore, Vashti's behaviour was regarded as a violation of the order of things in the society. Her behaviour made Persian men recognise female power of which men are often ignorant. Vashti speaks for the powerless and those disenfranchised by gender, race, sexual orientation or any other characteristic upon which the powerful build exclusion. Vashti was confronted with what she considered an injustice of not having her own right but she refused to participate in her own oppression. She knew her rights as a full human being and refused to allow any man to deny her of such rights. She was an individual who simply said ' $\mathrm{No}^{\prime}$ to society's expectation and evaluation of her. She was a strong-willed character with an independent mind whose courage is admirable. Vashti indeed refused to heed the king's request because she deemed it degrading. Thus, she can be regarded as being principled and forthright, a model to anyone who chooses to follow their conscience regardless of the cost (Day 2005:42-43).

Vashti's refusal therefore can serve as a starting point for women as well as men to resist wrongdoing in the society. Regardless of women's position in the society, keeping silent and accepting their situation is not always a solution. Following the example of Vashti, DR Congolese women theologians need to stand up against what they perceive to be immoral or unjust and uphold justice regardless of the consequences. As women resist patriarchy and all related injustices, their strength should lie in their ability to organise themselves and put pressure on the system. Vashti is seen as a strong character who did not use her beauty or sexuality for self-advancement. She valued herself as a woman and her identity as a human being was more important to her than her position as queen. In the same vein, with the emergence of various women's movements such as the Circle of Concerned African Women Theologians (the Circle), many women today have begun to say ' $\mathrm{No}^{\prime}$ ' in the interest of their well-being. They are no longer afraid to stand and speak out to protect their dignity. 
Therefore, DR Congolese female theologians need to arise and create a space where they can share their stories and say 'No' to marginalisation, abuse and the objectification of women in an egalitarian society and where they can fight for the right of women as human beings created in God's image. To resist marginalisation and oppression, one must speak up and be prepared to pay the price. Even if like Vashti we sometimes do not immediately reap the fruit, those who come after us can benefit from our actions, as did Esther who married a transformed king. Though Vashti was banished from the king's presence, he learned something from her that gave Esther the freedom to manipulate him. One agrees with Sakenfeld (2003:64) that saying 'No' should be regarded as a model for women and men alike. Female theologians should use Vashti as a model to resist marginalisation and all the injustices perpetrated against them in the society and within the church. Vashti seemed to know what she wanted and she did what was needed to achieve her goal irrespective of the repercussions.

\section{Re-enacting the Circle in the Democratic Republic of the Congo to empower female theologians}

The demand by African women theologians to transform our continent as well as the problems that confront women in the church and society should be recognised. Upholding women's empowering thoughts and actions is one way of spreading ideologies that they express in their speeches and writings. The message of women theologians is an important one that can help in finding solutions and providing some orientations on how to deal with problems of gender and the need to affirm women's presence in the society as a creative energy for the future of gender relationships. Therefore, because the Circle is one of such organisations that speak for women, it is time that it became active in the DRC as well.

The Circle of Concerned African Women Theologians which was created as a theological space for African women theologians to find and mentor each other seems to be absent or almost unknown among DR Congolese female theologians. Publications produced by Circle members based on their experiences are nowhere to be found. On the other hand, some DR Congolese women theologians express concerns that are similar to those of Circle women. For example, Sr. Bernadette Mbuy-Beya has written extensively on issues regarding women's sexuality and place in the society and church, particularly in the Congolese context. Unfortunately, her contributions which are mostly in English remain inaccessible to many readers because of the language barrier. Many Congolese female theologians are also surprised to hear of the existence of such a platform where women gather from different contexts to share their experiences. There is no official Circle chapter operating in the DRC as in other countries like those in Southern African. Why is the Circle of Concerned African Women Theologians well known on the international scene but remains unknown in the DRC, one of the largest African countries with a growing number of women theologians? What then can be done to promote the Circle among women theologians in the DRC? Women theologians in the DRC are willing to occupy such spaces where they can be empowered and can share their own experiences. These questions form our discussion in the next sections.

\section{Future of women theologians in the Democratic Republic of the Congo: The role of the Circle}

The Circle is a community of African women theologians who come together to reflect on what it means to be women of faith within their experiences of religion, culture, politics and socio-economic structures in Africa. According to Phiri (2008):

The Circle seeks to build the capacity of African women to contribute their critical thinking and analysis to advance current knowledge using a theoretical framework based on theology, religion and culture. It empowers African women to actively work for social justice in their communities and reflect on their actions in their publications. (p. 2)

The Circle serves as a platform where women, particularly theologians, come together to discuss their concerns. As argued by Hinga (1996:28), African women's theology is a protest against women's forced silence 'and a wakeup call to African women to rise and fight against the forces of injustice that surround them'. African women theologians seek to advance and understand from a Christian perspective the equality of men and women morally, socially, spiritually and in leadership. In their discourse, it is argued that God does not discriminate on the basis of biologically-determined characteristics such as sex and race (McPhillips 1999:257). The discussions focus on women's issues including the place and role of women within the church and society, ordination of women, male dominance in Christian marriage, recognition of equal spiritual and moral abilities and so on. The theology of the Circle includes the interests of both those who are in academia and those who express their theology in the form of spontaneous poetic lyrics, songs and prayers which are parts of everyday lives of ordinary women (Amoah 1995:1). The women read the Bible with a feminist lens considering the fact that the Bible was written in the context of certain cultures and traditions that were fully patriarchal in nature and that could have influenced the views of its authors. As such, they read the Bible based on the everyday experiences of women in order to empower and liberate women, thus, making their theologies explicitly contextual. This is a context marked by the struggle to survive against forces that deny their humanity such as globalisation and its consequences of poverty, debilitating diseases including HIV and AIDS and malaria, gender-biased legal systems, denial of human rights, oppressive traditions and exclusion from decision-making processes in church and society.

African women's theologies are therefore contextual liberation theologies, which are characterised by interrelationships, gender issues, justice and the transformation of individuals 
and society. The Circle of Concerned African Women Theologians emerged through this generation of theologians who emphasise 'doing' rather than 'thinking' theology, and who have attempted to be at the heart of where theology is being created, in the womb of the community of faith, to academically articulate what is being produced (Njoroge 1997:1). Thus, they are interested in articulating the voices, cries, tears, fears, silences, images, songs, sermons and prayers that are heard, seen and stored in the memory of the community of faith and in the society as people struggle to live out their faith. In doing theology, they consider the diversity within each religion and culture and avoid being simply a mass of people with everything in common.

The Circle has played and continues to play an important role in transforming the lives of women in general and of African women particular. Through their commitment to foster change in patriarchal African societies, the Circle has become a platform where not only women theologians but all women with different skills come together to discuss issues affecting women and the society as a whole. Therefore, with regard to the actual situation in the DRC, there is a strong need to recreate such a space where women should stand together and speak for themselves. It is time to identify women in theological institutions and urge them to work together as a community so that they can produce their own theology that seeks the liberation of women from oppression and discrimination. Such space should be used to empower women to contribute their unique voice to the continental and global theological voice on issues of women through writing and publishing.

Women theologians in the DRC should follow the example of their counterparts in Southern Africa where the Circle is more alive and the production of its theology is not limited only to those in theological institutions. The Southern African Circle has engaged with women from outside the disciplines of theology and religion within the academy. Its engagements have also meant the inclusion of women who are interested in issues that interface with culture, religion and women in Africa, but do not have any theological background (Phiri 2008:3). It is for this reason that the Circle claims that, 'elitism is not our way of life' (Oduyoye 2001:34). Their theology is done in the community of women in the academy and in the communities of faith.

Therefore, Congolese women theologians could use the Circle as a protest movement against any form of exclusion and discrimination. If the Circle becomes visible in the DRC, it could promote fullness of life as intended by God and help to increase the number of women studying and teaching theology. As argued by Kanyoro (2001), the Circle is:

\footnotetext{
... a gift to women because it has opened women's eyes to the fact that the future of society and the future of women depend on women placing their trust in the message of God rather than the message of men. (p. 171)
}

We can read the Bible by ourselves and engage various topics on women issues.

\section{Conclusion}

Women's well-being cannot improve without addressing issues that marginalised them. A woman's low self-esteem has becomes the basis on which the society exploits its women. DR Congolese women are faced with many forms of discriminations that prevent them from being educated and occupying leadership positions. This article has used the character of Vashti and her sense of independence and courage to motivate Congolese female theologians to come together and fight all form of abused within the society in general and the church in particular. The Circle of Concerned African Women Theologians plays an important role in transforming women's lives. It gives women a voice to speak up. Therefore, it is time for the DRC female theologians to follow the example of other countries or regions and develop the DRC Circle as a space where women, irrespective of their differences, can come together and speak for themselves. This article is a call for leadership of the Circle and all informed women theologians in the DRC to take bold steps to strengthen the Circle and publicise its activities among other DR Congolese women theologians. As human beings created in God's image, women are urged to fight for their integrity as persons in their own right (Ruether 1998:20-35). Empowerment is about having the choice to define what one's own version of success looks like at any stage of one's life. It is also about having the freedom to change that definition to fit one's stage and circumstances in life.

\section{Recommendations}

Because female theologians in the DRC need to resist abuse, injustice and marginalisation, resources should be mobilised to establish the Circle. The starting point might be to have a nationwide Circle conference that includes representatives from the different provinces which are capable of mentoring other women. The conference should highlight Circle objectives and encourage participants to do the same in their respective provinces as a way of promoting the Circle. Circle books should also be made accessible in theological institutions.

\section{As argued by Mbuy-Beya (1996):}

The struggle for the liberation of women and for the protection of creation concerns us all. Let the church spare no effort to preach against all forms of exploitation of women and children and against the destruction of the environment. (p. 186)

The struggle for women's liberation and the protection of God's creation concerns all. There should be collaboration between women theologians and men serving in theological faculties and church-based institutions to carry out curriculum reforms that would promote feminist or gender theological issues. Congolese women should take their place in the church without waiting for handouts and should participate in important decision-making that affects their lives and their communities.

Congolese female theologians should search for new ways of doing their theology which would liberate the Bible from 
misuse and affirm women. By raising these concerns, we are calling the church and our theological institutions to reexamine their theologies. Congolese theologians should use their communal power to get involved in activism as they work towards the transformation of their communities and institutions in the area of gender justice. They should come together to create a space where they can come up with the best ways to resolve issues relating to women and children and to human rights. The emphasis should be on the publication of books, articles and book chapters, and organising seminars about women's empowerment.

\section{Acknowledgements Competing interests}

The author declares that she has no financial or personal relationships which may have inappropriately influenced her in writing this article.

\section{References}

Amoah, E., 1995, 'Theology from the perspective of African women', in O. Ortega (ed.), Women's vision: Theological reflection, celebration and action, pp. 1-7, WCC Publications, Geneva.

Beal, T.K., 1997, The book of hiding gender, ethnicity, annihilation and Esther, Routledge, London.

Comstock, G.D., 1993, Gay theology without apology, Pilgrim Press, Cleveland, OH.

Day, L.M., 2005, Esther, Abingdon Old Testament commentaries, Abingdon Press, Nashville, TN.

Edewor, K., 2001, 'Cultural attitude to women's education and economic empowerment: A comparative study of men and women in ljebu Igbo', in D. Akintunde (ed.), African culture and the quest for women's right, pp. 35-49, Oluseyi Press, Ibadan.

Fiedler, R.N. \& Hofmeyr, J.W., 2011, 'The conception of the circle of concerned African women theologians: Is it African or western?' Acta Theologica 2011 (1), 1-57.

Goitein, S.D., 1959, Studies in the Bible, Yavne, Tel Aviv.
Hinga, T., 1996, 'Between colonialism and inculturation: Feminist theologies in Africa', in E. Schussler-Fiorenza \& S.M. Copeland (eds.), Feminist theology in different contexts, pp. 26-29, Concillium London, UK, SCM Press.

Hulstaert, B., 1964, Les Droits Fonciers Mongo, Centre Aequatoria Bamanya, Mbandaka.

Kanyoro, M.R.A., 2001, 'Engendered communal theology: African women's contribution to theology in the 21st Century', in J.N. Nyambura \& M.W. Dube (eds.), Talitha cum! Theologies of African women, pp. 158-178, Cluster Publication, Pietermaritzburg.

Kondemo, M.M., 2015, 'In search of affirming identities and role models: A gendersensitive re-reading of the Vashti and Esther characters in the book of Esther among the mongo of the Democratic Republic of the Congo', DTh thesis, University of South Africa.

Lerner, G., 1986, The creation of patriarchy, vol. 1, Oxford University Press, Oxford.

Mbuy-Beya, B., 1996, 'Women in the Churches in Africa. Possibilities for presence and promises', in M. Browne (ed.), The African Synod documents, reflections, perspectives, pp. 175-187, Orbis Book, New York.

McPhillips, K., 1999, 'Feminisms, religions, cultures and identities', Australian Feminist Studies 14 (30), 255-258. http://dx.doi.org/10.1080/08164649993083

Nadar, S., 2002, 'Gender, Power, Sexuality and Suffering Bodies in the Book of Esther: Reading the Characters of Esther and Vashti for the Purpose of Social Transformation', Old Testament Essays 15(1), 113-130.

Njoroge, N.J., 1997, The missing voice African women doing theology. Women and men in partnership programme, viewed 31 December 2015, from http://web.uct. ac.za/depts/ricsa/jtsa/j99/j99njoro.htm

Oduyoye, M.A., 2001, 'Keynote address', in D. Akintunde (ed.), African culture and the quest for women's rights, pp. 1-10, Oluseyi Press, Ibadan.

Olatundun, O., 2010, 'Bridging gender equity gap in Africa: A Psycho historical exposition of Efunsetan Aniwura llesanmi', viewed 20 February 2014, from http:// www.academicjournals.org/IJPC

Phiri, A.I., 2008, 'Major challenges for African women theologians in theological education (1989-Phiri, I. A., 2008)', viewed 24 October 2015, from http://hdl. handle.net/10500/4525

Ruether, R.R., 1998, Women and redemption: A theological history, Fortress Press, Minneapolis, MN.

Sakenfeld, K.D., 2003, Just Wives? Stories of power and survival in the Old Testament and today, John Knox Press, Louisville, KY.

Tamez, E., 1994, 'Women's reading of the Bible', in U. King (ed.), Feminist theology from the third world: A reader, pp. 191-201, Orbis Books, New York.

White, P., 2015, A cry for freedom: The African women's quest in the light of the bible, viewed 17 September 2015, from http://hdl.handle.net/123456789/314

Zonana, J., 1996, 'Feminist providence: Esther, Vashti, and the duty of disobedience in nineteenth-century Hermeneutics', in J.C. Hawley (ed.), Through a glass darkly: Essays in the religious imagination, pp. 228-249, Fordham University Press, New York. 